\title{
PEDAGOGY
}

\section{НАВИЧКИ ПРОТИДІї НАСИЛЬСТВУ В УЧНІВСЬКОї МОЛОДІ}

\author{
Лаврентьєва I. В., \\ асn., Інститут проблем виховання НАПН Украӥни, м. Київ, Украӥна, \\ ORCID ID: https://orcid.org/0000-0003-4085-6228
}

Воронцова T. В., дои., Національний педагогічний університет імені М.П. Драгоманова, м. Київ, Украӥна, ORCID ID: https://orcid.org/0000-0002-0728-4072

Хомич О. Л., канд. пед. наук, Інститут проблем виховання НАПН Украӥни, м. Київ, Украӥна, ORCID ID: https://orcid.org/0000-0002-2947-4731

DOI: https://doi.org/10.31435/rsglobal_ws/30062020/7115

\section{ARTICLE INFO}

Received: 05 April 2020

Accepted: 03 June 2020

Published: 30 June 2020

\section{KEYWORDS}

violence,

student youth,

violence prevention,

life skills.

\begin{abstract}
In this article considers the problem of violence among modern student youth. Provided the definitions of notions «violence», «bulling» and «violence among student youth», considered the main participants of this phenomenon (the abuser, the victim, and the observer) and their psychological portraits. Described the types of violence (physical, psychological, sexual) and forms of their manifestation in general secondary education among students. Identified the main factors of the occurrence of violence at the student environment. The emphasis has been placed on the problem of violence should be solved through the cooperation of the state, the community, educational institutions and parents. Has been formed the list of characteristics that should combine a successful prevention program for combating violence through the analysis of the world's successful preventive practices. In particular, the orientation of such practices to the formation and development of life skills that encourage positive behavioral shifts. Has been formed the list of life skills that contribute to combating and preventing violence.
\end{abstract}

Citation: Lavrentieva I. V., Vorontsova T. V., Khomych O. L. (2020) Skills of Counteraction to Violence Between Student Youth. World Science. 6(58), Vol.3. doi: 10.31435/rsglobal_ws/30062020/7115

Copyright: (C) 2020 Lavrentieva I. V., Vorontsova T. V., Khomych O. L. This is an open-access article distributed under the terms of the Creative Commons Attribution License (CC BY). The use, distribution or reproduction in other forums is permitted, provided the original author(s) or licensor are credited and that the original publication in this journal is cited, in accordance with accepted academic practice. No use, distribution or reproduction is permitted which does not comply with these terms.

Актуальність проблеми дослідження. Успішне навчання і повноцінний розвиток особистості можливі лише за безпечних та сприятливих умов у закладі освіти - основному соціальному середовищі учня. Однак цьому нерідко перешкоджає низка деструктивних чинників, чи не найважливішим з яких є проблема насильства в молодіжному середовищі, яка стає все більш поширеною у сучасному світі. Насильство призводить до збільшення рівня агресії в учнівському середовищі, невиправданої ескалації конфліктів і як наслідок - до виникнення в учнів емоційних і психологічних проблем, зниження академічної успішності, збільшення ризику суїциду серед молоді. У зв'язку з цим виникає потреба досліджувати як сам феномен насильства в освітньому середовищі, так і його причини, оскільки це вкрай негативно позначається на психоемоційному фоні освітнього закладу. Дані вітчизняних досліджень (I. Кон, М. Нечаєва, О. Селіванова, Т. Шевцова та ін.) вказують на високу ступінь поширення 
цього явища серед учнівської молоді. Вони свідчать, що більш як $60 \%$ учнів стикалися 3 різними видами агресії і цькування. Як відзначають дослідники І. Волкова, Н. Моїсеєва, М. Сафронова, Д. Соловйов та ін., у закладах освіти все частіше спостерігаються випадки жорстокості, приниження i знущання, які стають причинами особистісних деструкцій, депресивних станів, соматичних і автоімунних захворювань, спроб суїциду.

Аналіз останніх досліджень і публікацій. Аналіз психолого-педагогічних джерел і виховної практики засвідчує, що проблему насильства активно досліджують науковці всього світу. Першими науковцями, які розпочали досліджувати проблематику насильства вважають вчених Д. Олвеуса, А. Пікаса, Є. Роланда, П. Хайнеманна.

Теоретично обгрунтували та експериментально довели, що агресія органічно пов’язана 3 насильством і є його природним підгрунтям А. Бандура, Р. Берон, А. Браун, К. Бютнер, Н. Міллер, А. Мічерліх, О. Маурер, Д. Річардсон, З. Фройд, З. Холл, В. Холичер та ін.

Над розробкою й впровадженням програм 3 профілактики шкільного насильства працювали: Р. Новако, Д. Ольвеус, Е. Роланд, Е. Руланн, К. Салміваллі, П. Хайнеманн та ін.

До розкриття проблеми булінгу зверталися Т. Алєксєєнко, Т. Веретенко, В. Петросянц (булінг як соціально-педагогічне явище у шкільному середовищі); М. Аряєв, І. Шевченко (регіональні характеристики прояву насильства); Р. Безпальча, І. Гайдамашко, А. Губко, М. Жданова, Н. Заверико, О. Романова, Л. Лушпай, Д. Соловйов, А. Чернякова (психологічні особливості учасників булінгу i впровадження інноваційних технологій профілактики агресивної поведінки в умовах закладу загальної середньої освіти) та ін.

Мета роботи - проаналізувати і узагальнити проблему профілактики насильства серед учнівської молоді.

Виклад основного матеріалу. Проблематика насильства розглядається науковцями різних галузей, відповідно є багато підходів до трактування дефініції «насильство». В Академічному тлумачному словнику зазначено, що насильство - це застосування фізичної сили до кого-небудь (Словник Української Мови, 2020).

В Українській психологічній термінології термін «насильство» подається, як застосування силових методів або психологічного тиску за допомогою погроз, свідомо спрямованих на слабких або тих, хто не може чинити опір; панування, влада людини над людиною (Чепи, 2010). Тобто, будь-яке застосування сили щодо беззахисних.

Згідно з визначенням Всесвітньої організації охорони здоров'я (ВОО3): насильство - це навмисне застосування фізичної сили, спрямованої проти іншої особи або групи осіб, результатом якого є тілесні ушкодження, психологічна травма, відхилення в розвитку або смерть. Насильство відрізняється від інших дій тим, що воно носить навмисний характер (Глазырина \& Костенко, 2015).

На нашу думку, найбільш релевантним для мети і завдань нашого дослідження $\epsilon$ трактування поняття дослідниками Кириченко В. і Нечерда В. (2019), які розглядають насильство, як застосування сили у стосунках між учнями або вчителями стосовно учнів, рідше - учнів стосовно вчителів, жорстоке ставлення до особистості у різних формах (зокрема, фізичній, психологічній або емоційній), нехтування іiі інтересами та потребами 3 метою завоювання, збереження, панування прав, привілеїв іншої особистості (групи).

Починаючи із 2006 року випадки насильства серед учнівської молоді повільно та все ж скорочуються (рис. 1). Разом з тим, почастішали випадки особливо жорстоких форм насильства, тому проблема дослідження цього явища та шляхів попередження актуальна як ніколи.

Фактори виникнення насильства в середовищі учнівської молоді можна класифікувати на: індивідуальні (агресія, віктимність, конформність підлітків) та групові (антисоціальна групова діяльність, несформована ціннісна орієнтація єдності групи, відсутність самовизначення особистості в групі у іiі учасників, несприятливий соціально-психологічний клімат групи). Важливо підкреслити, що насильство в учнівському середовищі являє собою форму взаємодії, в якій проявляються різні типи поведінки, зокрема основні дійові особи: кривдник, жертва, спостерігач (Петросянц, 2011).

Кривдники - це учні, які мають соціальну вагу або наділені більшою фізичною силою, 3 високим рівнем агресивності, що спрямована на інших учнів. Найчастіше насильство ініціюють надміру агресивні діти, які люблять домінувати, тобто бути «головними». Їх не турбують почуття і переживання інших людей, вони прагнуть бути в центрі уваги, контролювати все 
навколо. Принижуючи інших, вони підвищують власну значущість. Нерідко це відбувається через глибокі психологічні комплекси кривдників. Можливо, вони самі переживали приниження або копіюють ті агресивні й образливі моделі поведінки, які є у їхніх сім’ях.

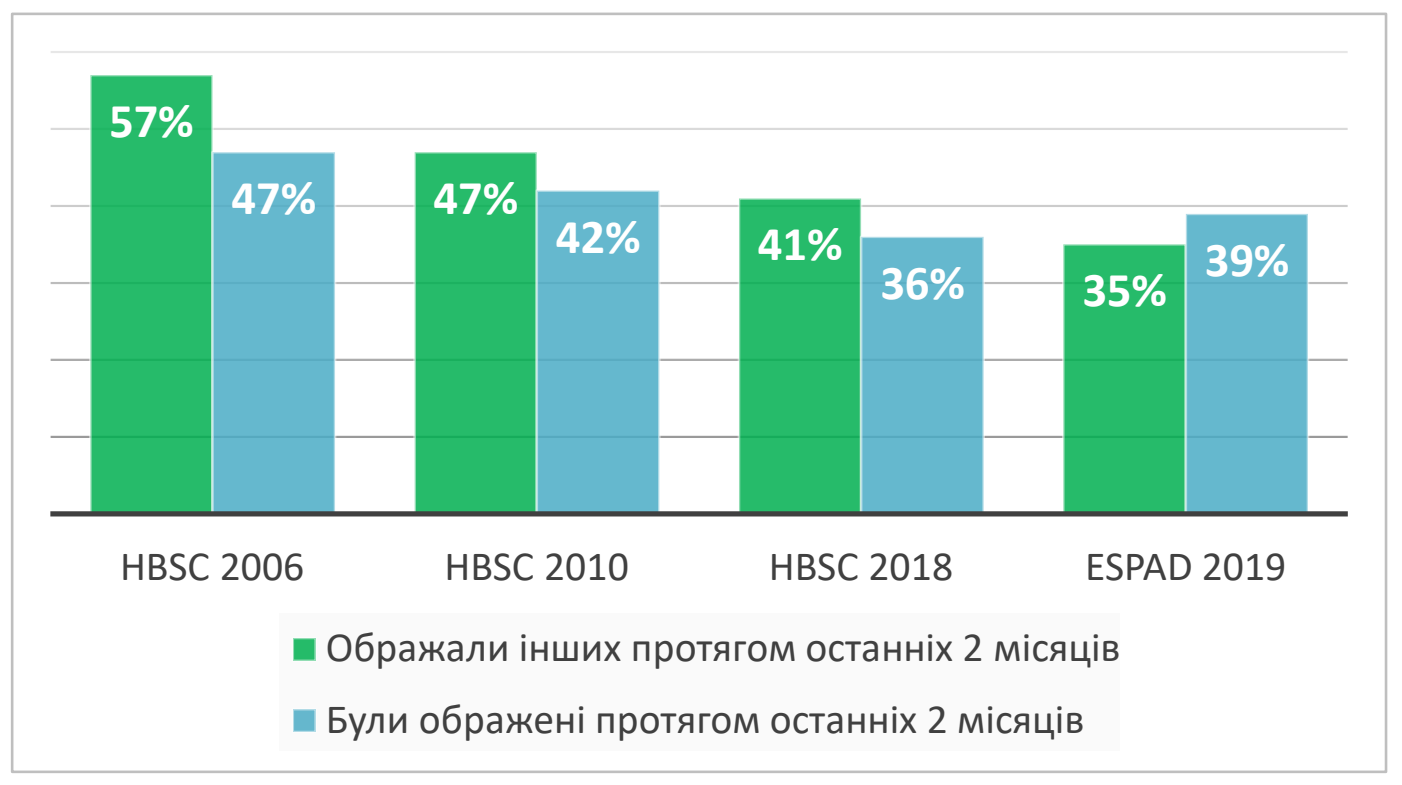

Рис. 1. Динаміка насильства серед учнівської молоді в Украӥні (Балакірєва, 2018)

Жертви - це учні, які є об'єктами знущань. Зазвичай об'єктом знущань вибирають тих, у кого $є$ дещо відмінне від однолітків. Відмінність може бути будь-якою: особливості зовнішності; манера спілкування, поведінки; незвичайне захоплення; соціальний статус, національність, релігійна належність (Плутицька, 2017; Вчимося Жити Разом, 2020).

Спостерігачі - це учні, які спостерігають за насильством. Спостерігачі проявів насильства в учнівському середовищі можуть позитивно чи негативно відноситися до конкретної ситуації, але незмінно не роблять жодних активних дій (не допомагають ані кривднику, ані жертві). Та лише своєю присутністю вони $є$ підкріплюючим фактором для кривдника, який часто вдається до насильства, коли є «глядач» (Газман, 2009).

Людину, яку вибрали жертвою і яка не може постояти за себе, намагаються принизити, залякати, ізолювати від інших різними способами. Насильство це не лише завдання фізичної шкоди, розрізняють фізичне, психологічне та сексуальне насильство (рис. 2).

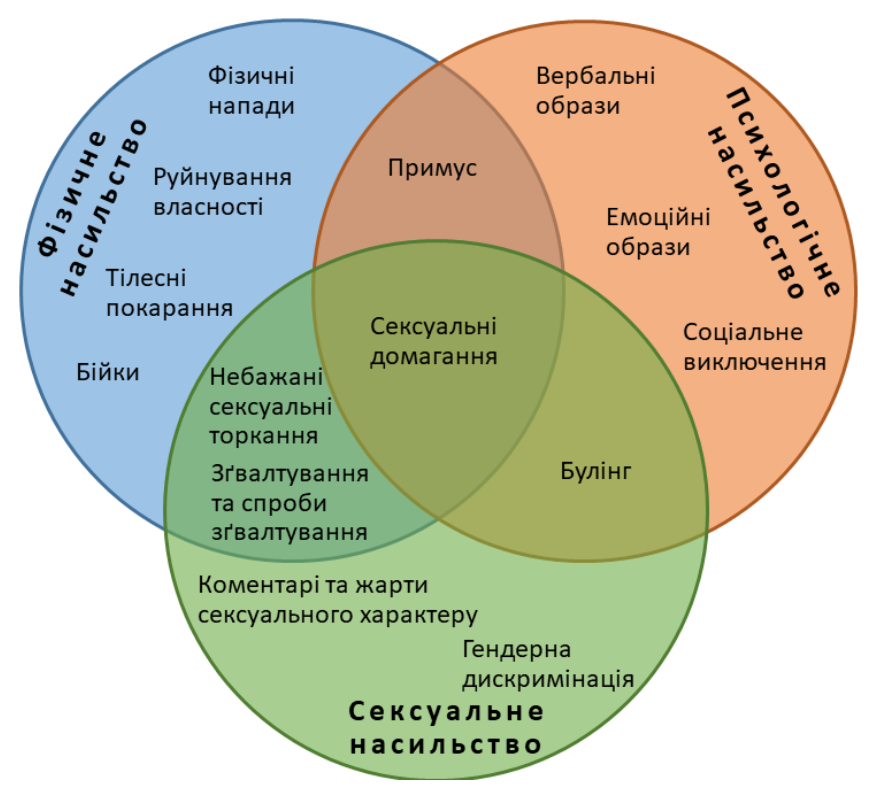

Рис. 2. Типологія булінгу та насильства (Балакірєва, 2018) 
70 \% випадків насильства випадає на долю психологічного: принизливі обзивання, глузування, жорстока критика, висміювання та ін. На жаль, кривдник часто залишається непоміченим і непокараним, однак образи безслідно не зникають для об'єкта приниження. Найскладніше помітити соціальне виключення, яке проявляється через систематичне приниження почуття гідності потерпілого, ігнорування, ізоляцію, уникання (Вчимося жити разом, 2020).

Фізичне насильство найбільш помітне, однак становить менше третини випадків булінгу (нанесення ударів, штовхання, підніжки, пошкодження або крадіжка особистих речей жертви та ін.).

Випадки сексуального насильства загострюються саме у підлітковий період, коли вчорашні діти набувають зовнішніх статевих ознак. Найчастіше це явище проявляється у вигляді глузувань, недоречних жартів, стереотипних висловлювань та образ жертв за гендерними ознаками.

Основними факторами, що пояснюють жорстокість кривдників по відношенню до жертви, є (Педагогічний портал, 2019):

особистісна агресивність, що залежить від індивідуальних особливостей, яка загострюється у підлітковий період;

попередній життєвий досвід, що включає прояви власної агресивності і спостереження аналогічних проявів у найближчому оточенні - в сім'ї, в закладах освіти, відвідуваних раніше;

недостатній рівень розвитку комунікативних навичок, в тому числі відсутність прикладів і досвіду ненасильницьких стосунків і знань про свої права та права інших;

особливості шкільного середовища, до яких слід віднести:

а) загальний психоемоційний фон, який характеризується високим рівнем тривожності і психічної напруженості суб' єктів взаємодії в сукупності з невмінням контролювати власні емоції;

б) «політичну» систему закладу освіти, що включає агресивні взаємовідносини всередині педагогічного колективу, в тому числі авторитарно-директивний стиль управління, відсутність обгрунтованої системи педагогічних і професійних вимог, особливо ставлення педагогів до школярів, побудовані на необгрунтованих вимогах 3 боку дорослих i максимальному безправ”і дітей;

в) систему взаємовідносин усередині класу, в основі якої принципи влади i підпорядкування та наявність загальновизнаних соціальних ролей, що включають ролі «жертви» і «кривдника» (Селиванова \& Шевцова, 2011).

Таким чином, насильство серед учнівської молоді - це тип деструктивної конфліктної взаємодії, при якій кривдником здійснюються тривалі повторювані насильницькі дії по відношенню до жертви.

Для того, щоб зупинити насильство у закладах освіти, Дитячий фонд ООН (ЮНІСЕФ) закликає до невідкладних дій у таких напрямках: впровадження законів, необхідних для захисту учнів від насильства в школах; посилення заходів із запобігання та реагування на насильство в школах; заохочення громад та окремих осіб підтримувати учнів, коли вони говорять про насильство, а також працювати над підвищенням культури спілкування в школах та громадах; збір більш докладних даних про насильство проти дітей у школах і розповсюдження інформації про дієві методи запобігання і протидії насильству (Педагогічний портал, 2019).

Впроваджуючи в Україні принципи сучасного демократичного суспільства, з метою запобігання насильству в закладах освіти Верховна Рада 18.12.2018 ухвалила закон «Про внесення змін до деяких законодавчих актів України щодо протидії булінгу (цькування)». У документі було визначено поняття булінгу, шляхи протидії цьому явищу і захисту прав дітей, а також інших осіб, які працюють у навчальному закладі. Законом запроваджується адміністративна відповідальність за булінг (Про внесення змін, 2019).

Зважаючи, що учнівська молодь найбільше часу проводить у закладах загальної середньої освіти, які мають ресурси для впровадження профілактичних програм, але не завжди володіють якісним навчально-методичним інструментарієм, саме 33СО мають бути основним плацдармом для боротьби з насиллям. Ефективні профілактичні програми мають ряд спільних ознак, виокремлених в результаті дослідження таких програм у всьому світі. Проаналізувавши успішні превентивні практики, ми сформували перелік ознак ефективної програми 3 профілактики насильства [ЮНЕСКО, 2018; УНП ООН, 2015). Така програма має бути:

розроблена фахівцями, зокрема педагогами та психологами; 
складена з урахуванням психолого-фізіологічних особливостей учнівської молоді; містити чітко означені завдання (результати навчання);

розбудована на засадах особистісно-орієнтованого та компетентнісного підходів; наповнена інтерактивними вправами та активностями, зокрема прикладами реальних життєвих ситуацій, де має місце насильство та способи протидії або попередження таких ситуацій; орієнтована на залучення молоді до активної участі у вирішенні конфліктів, зокрема, за допомогою методу «рівний-рівному»;

націлена на формування і розвиток життєвих навичок, які сприяють попередженню та протидії насильства.

Профілактичні програми мають бути націлені на якісні позитивні поведінкові зміни, що $\epsilon$ здійсненним при орієнтації на формування та розвиток життєвих навичок (соціальнопсихологічних компетентностей), сприятливих для вирішення поставлених завдань.

За визначення ВООЗ життєві навички - це здатність до адаптації, позитивної поведінки та подолання труднощів щоденного життя. Чітко визначеного переліку життєвих навичок не існує, їх налічують близько двадцяти. Найчастіше їх поділяють на ті, що сприяють соціальному та психологічному благополуччю, останні в свою чергу поділяються на когнітивні (інтелектуальні) та емоційно-вольові (Воронцова та ін., 2017).

Нами було сформовано уточнений перелік життєвих навичок, які спрямовані саме на протидію та попередження насильства серед учнівської молоді.

До життєвих навичок, що сприяють соціальному благополуччю, належать:

1. Навички ефективного спілкування:

чітко і спокійно висловлювати свою думку і позицію, без звинувачення;

вислуховувати думку співрозмовника;

відкрито висловлювати свої почуття, використовувати «Я - повідомлення»; просити про послугу, допомогу.

2. Навички співпереживання:

розуміти почуття, потреби і проблеми людей, які страждають від насильства; правильно висловлювати це розуміння, надавати їм підтримку і допомогу.

3. Навички розв'язання конфліктів:

розпізнавати конфліктні ситуації;

уникати ескалації конфліктів;

втручатися і застерігати інших від конфліктів перш, ніж вони загостряться;

знаходити і впроваджувати мирні способи вирішення конфліктів.

4. Навички протидії соціальному тискові (упевненої поведінки, відмови, поведінки в умовах тиску, загрози насилля, протидії дискримінації):

адекватно діяти у разі виникнення ситуації дискримінації, загрози насильства;

протидіяти тиску з боку однолітків і дорослих щодо участі в насильницьких діях;

упевнено відмовлятися підтримувати насильницькі дії;

долати сором'язливість у разі необхідності звернутися за допомогою в ситуаціях

боулінгу, кібербулінгу.

5. Навички адвокації і захисту:

брати участь у заходах, які пропагують ненасильницьку поведінку;

організацій;

приєднуватися, підтримувати i інформувати інших щодо ненасильницьких дій i

відмовляти інших від перегляду фільмів і відеоігор, які пропагують насильство.

Також виділено життєві навички, що сприяють психологічному благополуччю (внутрішньоперсональні навички).

I. Когнітивні (інтелектуальні навички):

1. Самоусвідомлення і самооцінки:

здатність усвідомити свою унікальність;

позитивне ставлення до себе, інших людей і життєвих перспектив;

усвідомити власні цінності і відстоювати їх в умовах тиску.

2. Аналіз проблем і прийняття рішень:

розуміти ролі жертви, агресора, спостерігача;

знаходити надійні джерела допомоги протидії насильству; 
визначати можливі ситуації насильства;

визначати варіанти дій у ситуаціях насильства;

оцінювати наслідки цих варіантів для себе й інших людей.

3. Навички критичного мислення:

розпізнавати і розвінчувати стереотипи у соціальному оточенні;

аналізувати власні стереотипи, переконання і уявлення, які підтримують насильство;

розрізняти насильство і дружні піддражнювання;

аналізувати вплив однолітків і засобів масової інформації щодо насильства;

оцінювати насильницькі і ненасильницькі рішення, які транслюються через засоби масової інформації;

допомогти зменшити упередження і збільшити толерантність щодо відмінностей, які існують між людьми.

II. Емоційно-вольові навички:

1. Навички самоконтролю, керування стресом:

контроль проявів гніву;

уміння долати тривогу;

уміння справлятися з травмою, насиллям;

у разі потрапляння у ситуацію насильства якнайшвидше опанувати себе i налаштуватися на боротьбу за своє життя.

2. Мотивація успіху і гартування волі:

вірити в те, що можна протидіяти насильству;

налаштуватися на успіх у боротьбі з насильством.

Висновки. Таким чином, насильство серед учнівської молоді - це тип деструктивної конфліктної взаємодії, при якій кривдником у відношенні до жертви здійснюються тривалі повторювані насильницькі дії. Не зважаючи на широку увагу науковців різноманітних напрямів до цього явища, проблема набуває нових форм і проявів, зокрема частішають випадки особливо жорстоких прецедентів серед учнівської молоді. Також проблемою переймаються міжнародні організації, які закликають країни боротися із насильством в учнівському середовищі на державному рівні. Так, в Україні доопрацювали законодавчі акти щодо протидії булінгу. Однак здійснення превентивного впливу $є$ найкращим варіантом подолання проблеми насилля. Саме тому потрібно розробляти та впроваджувати ефективні профілактичні програми протидії насиллю, які поєднують в собі риси успішного національного досвіду та кращих світових практик. Так як будь-яка ефективна профілактична програма ставить за мету позитивні поведінкові зрушення цільової групи, для протидії насиллю потрібно формувати в учнівської молоді життєві навички, що сприяють вирішенню проблеми. В подальшому необхідна цілеспрямована робота щодо розроблення навчально-методичного забезпечення з протидії насильства серед учнівської молоді для поширення у закладах освіти.

\section{ЛIТЕРАТУРА}

1. Балакірєва, О. (2018). Насильство та булінг в освітньому середовищі: Результати соціологічного дослідження «Здоров'я та поведінкові орієнтації учнівської молоді (НВSC)». Взято 3 https://kubg.edu.ua/images/stories/podii/2018/10_26_bullying_02.pdf?fbclid=IwAR04lteMYBcMBIGpYT 8tsD8Ofym4zmf6Os5ZwrgV1sfwc0cqUseVQaJnbqw

2. Воронцова, Т. В., Пономаренко, В. С., Хомич, О. Л., Гарбузюк, І.В., Василенко ... Калмиков М. П. (2017). Вчимося жити разом: Посібник для вчителя з розвитку соціальних навичок у курсі «Основи здоров'я» (основна і старша школа). Київ: Видавництво «Алатон».

3. Вчимося жити разом. Курс підготовки вчителів (2020). Протидія булінгу Взято з: http://lit.multycourse.com.ua/ua/page/22/103.

4. Газман, О. Л. (2009). Психологические особенности участников буллинга. Известия Российского государственного педагогического университета имени А. И. Гериена, 10, 159-165.

5. Глазырина, Л. А. \& Костенко, М. А. (2015). Предотвращение насилия в образовательных учреждениях. Москва: БЭСТ-принт

6. Максимова, Н. Ю. (2014). Школьный буллинг. Рекомендации учителям, психологам, администрациям школ. Педагогика, 4, 34-39.

7. Нечерда, В. Б. \& Кириченко, В. І. (2019). Підлітки уразливих категорій: типологія $і$ особливості виховання в умовах закладів загальної середньої освіти. м. Кропивницький: Імекс-ЛТД 
8. Педагогічний портал: освітня преса (2019). «Булінг - важлива проблема для дітей в Украӥні. ЮНІСЕФ розпочинає кампанію проти булінгу». Взято з http: // pedpresa. ua / 185372-buling-vazhlyvaproblema-dlya-ditej-v-ukrayini-yunisefrozpochynaye-kampaniyu-proty-bulingu. html

9. Петросянц, В. Р. (2011). Психологическая характеристика старшеклассников, участников буллинга в образовательной среде, и их жизнестойкость. (Дисс. канд. психол. наук) Государственное образовательное учреждение высшего профессионального образования «Российский государственный педагогический университет им. А. И Герцена», Санкт-Петербург.

10. Плутицька, К. М. (2017). Підходи до розуміння булінгу як форми шкільного насильства. Науковий вісник Міжнародного гуманітарного університету, 29, 78-80.

11. Про внесення змін до деяких законодавчих актів України щодо протидії булінгу (цькуванню). № 5, ст. 33 (2019)

12. Селиванова, О. А. \& Шевцова, Т. С. (2011). Профилактика агрессивности и жестокости в образовательном учреждении. Тюмень: Издательство Тюменского государственного университета.

13. Словник української мови. Академічний тлумачний словник (2020). «Насильство». Взято 3 http://sum.in.ua/s/nasyljstvo

14. УНП ООН (2015). Міжнародні стандарти з профілактики вживання наркотиків. Взято 3 https://udpu.edu.ua/images/news/old/2018/09/06/3742/files/mijnarodni-standarti-z-profilaktiki-281-29.pdf

15. Чепи, Л. А. (Ред.). (2010). Українська психологічна термінологія : словник-довідник. Київ: ДП «Інформ.-аналіт. агентство»

16. ЮНЕСКО (2018). Международное техническое руководство по сексуальному образованию: Составлено на основе фактов и научных данных. Москва: ООО ПК «Янус» 